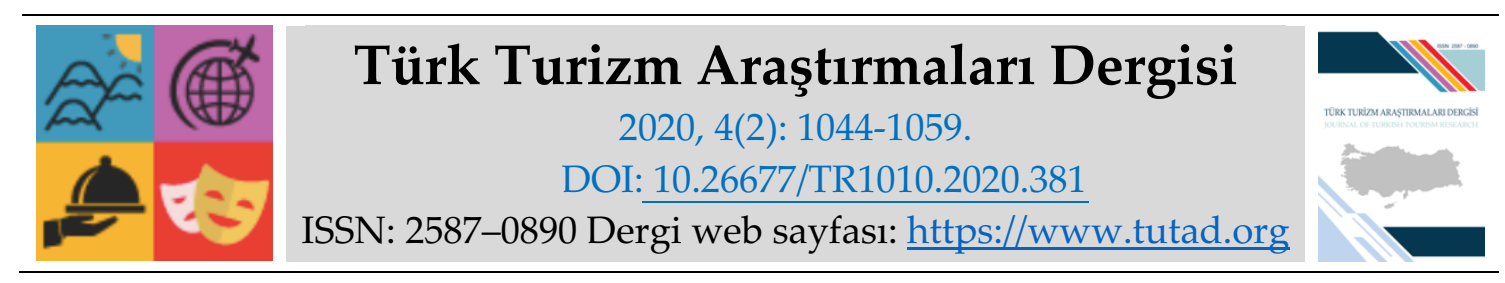

\title{
ARASTTIRMA MAKALESI
}

\section{İnanç Turizmi Açısından Deyrulzafaran Manastırı ve Ziyaretçi Profili Üzerine Bir İnceleme}

Doç. Dr. Adnan ALKAN, Siirt Üniversitesi, Fen-Edebiyat Fakültesi, Siirt, e-posta: ad alkan@hotmail.com

ORCID: https://orcid.org/0000-0002-5377-4726

Öz

Bu çalışmada Deyrulzafaran Manastırı'nın (Mardin) dini ve kültürel önemi ile manastırı ziyaret eden ziyaretçi profili incelenmiştir. Yıl içerisinden 200.000'den fazla ziyaretçi kabul eden manastır, inanç turizmi açısından büyük bir potansiyele sahiptir. Çalışmada yöntem olarak anket tekniği uygulanmıştır. Buna göre gelen ziyaretçi profilini tespit etmek için basit rasgele örnekleme yöntemine göre seçilen 400 birey ile bir anket yapılmıştır. Anketten elde edilen veriler SPSS 22 paket programında betimleyici istatistiklerden yararlanılarak ve çeşitli istatistiksel analizler kullanılarak çözümlenmiş ve yorumlanmıştır. Buna göre; manastırı ziyaret eden ziyaretçilerin daha çok kadınlardan oluştuğu, yaş gruplarının çoğunlukla 18-35 yaş aralığındaki genç nüfustan ve yüksek eğitim düzeyine sahip bireylerden oluştuğu gözlenmektedir. Ziyaretçilerin \%97'sinden fazlası ülke içinden gelirken, geriye kalanı ise Almanya, İsveç ve Kanada gibi ülkelerden gelmektedir. Manastırın mimari yapısı ve oluşturduğu ambiyans, ziyaretçiler tarafından en fazla beğenilen unsurlar olarak göze çarpmaktadır. Sonuç olarak Deyrulzafaran Manastırı, dini ve kültürel değeri dikkate alındığında Türkiye' deki İnanç turizmi bakımından önemli bir değer ve büyük bir potansiyel barındırdığı çalışmayla birlikte ortaya konmuştur.

Anahtar Kelimeler: İnanç, Kültür, Turizm, Manastır, Deyrulzafaran.

Makale Gönderme Tarihi: 05.02.2020

Makale Kabul Tarihi: 14.04.2020

\section{Önerilen Atıf:}

Alkan, A. (2020). İnanç Turizmi Açısından Deyrulzafaran Manastırı ve Ziyaretçi Profili Üzerine Bir İnceleme, Türk Turizm Araştırmaları Dergisi, 4(2): 1044-1059.

(c) 2020 Türk Turizm Araştırmaları Dergisi. 


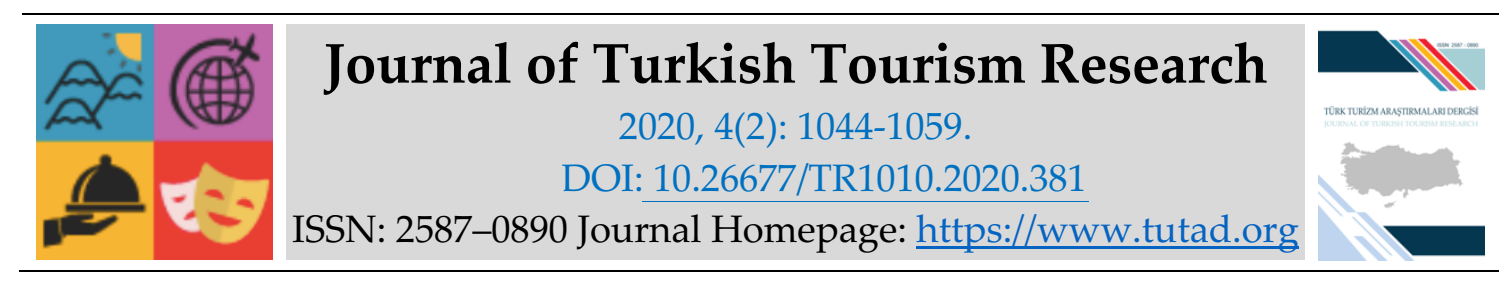

\title{
$\underline{\text { RESEARCH PAPER }}$
}

\section{A Study on Deyrulzafaran Monastery and Visitor Profile in Terms of Religious Tourism}

Associate Prof. Dr. Adnan ALKAN, Siirt University, Faculty of Science and Literature, Siirt, email:ad_alkan@hotmail.com

ORCID: https://orcid.org/0000-0002-5377-4726

\begin{abstract}
In this study, the religious and cultural importance of Deyrulzafaran Monastery (Mardin) and the visitor profile visiting the monastery were examined. Accepting more than 200.000 visitors during the year, the monastery has a great potential in terms of faith tourism. In the study, the survey technique was applied as a method. Accordingly, a survey was conducted with 400 individuals selected according to the simple random sampling method to determine the visitor profile. The data obtained from the survey were analysed and interpreted in SPSS 22 package program by using descriptive statistics and using various statistical analyses. According to this; It is observed that the visitors visiting the monastery consist mostly of women, the age groups mostly consist of young population between the ages of 18-35 and individuals with higher education level. Over $97 \%$ of visitors come from within the country, while the rest come from countries such as Germany, Sweden and Canada. The architectural structure of the monastery and its ambiance stand out as the most liked by the visitors. As a result, Deyrulzafaran Monastery, an important value in terms of faith tourism in Turkey Given the religious and cultural values and with work that demonstrated a big potential.
\end{abstract}

Keywords: Faith, Culture, Tourism, Monastery, Deyrulzafaran.

Received: 05.02.2020

Accepted: 14.04 .2020

\section{Suggested Citation:}

Alkan, A. (2020). A Study on Deyrulzafaran Monastery and Visitor Profile in Terms of Religious Tourism, Journal of Turkish Tourism Research, 4(2): 1044-1059.

(C) 2020 Türk Turizm Araştırmaları Dergisi. 


\section{Gíriş}

Günümüzde turizmin yarattı̆̆ı ekonomik, sosyal, kültürel ve politik etkiler, özellikle uluslararası ekonomik ve politik ilişkilerde oynadığı rol giderek önem kazanmaktadır (Sevinç ve Azgün, 2012:17). Bu bakımdan turizmin son yıllarda gösterdiği gelişme hızı nedeniyle 21. yüzyılın en büyük ekonomik faaliyeti olacağı öngörülmektedir (Özgüç, 2007:1) Bu durum, yalnız uluslararası turizm hareketinden büyük pay alan gelişmiş ülkelerde değil, aynı zamanda gelişmekte olan ülkelerde de turizme verilen önemi artırmaktadır. Bununla birlikte turizm, uluslararası ölçekte geniş istihdam olanakları yaratan bir sektör olup, Dünya Turizm Örgütü verilerine göre 2018 yılında uluslararası turizme katılan kişi sayısı 1 milyar 407 milyon kadardır. Aynı yılda turizmden elde edilen gelir ise 1,7 trilyon Amerika Birleşik Devletleri Doları olmuştur. Önceki yıla göre uluslararası turizme katılan kişi sayısı \%6, turizm gelirleri de $\% 5$ oranında artış göstermiştir (Union National World Tourism Organization, 2019).

Turizmin bu denli hızlı gelişmesi, kendi içerisinde çeşitlenmeye ve kültür, miras, inanç, sağlık ve ekoturizm gibi alternatif turizm türlerinin doğmasına yol açmıştır (Alaeddinoğlu ve Yıldız, 2007:21; Reisinger, 2009:9). Bu turizm türleri gelecekteki turizm pazarı için büyük bir potansiyel barındırmaktadır. (McKercher ve Cros, 2002:13). Özellikle kültür, miras ve inanç turizmi birbirlerinin gelişimlerini destekleyerek, yeni turizm türleri içerisinde en hızlı gelişme gösteren turizm formlardır. Turizmle inanç arasında geçmişten günümüze yakın bir ilişki gelişmiştir. Çünkü erken dönemlerden beri inanç, seyahat için güçlü bir motivasyon kaynağı olmuştur (Henderson, 2002:447-456). Günümüzde turizm trendinde yaşanan değişimler; turistlerin dinlenmek ve tatil geçirmek dışında; eğitim ve bilgi seviyesini arttırmak, dünya görüşünü geliştirmek, yeni yerler keşfetmek ve onların tarihi, yaşam biçimi ve kültürü hakkında bilgi sahibi olmak, dini gereklerini yerine getirmek, dini alanları ziyaret ederek manevi huzur aramak gibi motivasyonlara bağlı olarak güdülendiklerini göstermektedir (Okuyucu ve Somuncu, 2013:629). $\mathrm{Bu}$ güdülenme sonucunda ortaya çıkan inanç turizm, İnsanların dini amaç ve görevlerini gerçekleştirmek ve çeşitli dinler için önemli olan inanç merkezlerini görmek amaciyla gerçekleştirdikleri ziyaretlerin turizm olgusu içerisinde değerlendirilmesidir (Sargın, 2006:3; İçöz, 2003:6). İnanç turizmi de diğer tüm turizm tiplerinde olduğu gibi yapıldığı bölge için çeşitli avantajlar sağlamaktadır. Bu avantajların en başında hiç kuşkusuz yörenin ekonomik kalkınmasına yönelik sağladığ1 girdiler gelmektedir (Sevinç ve Azgün, 2012:19, Kaya vd., 2013:13). İnanç turizmi kapsamında gerçekleştirilen seyahatlerde, milyonlarca insan farklı şehirlere, bölgelere veya ülkelere gitmekte ve gittikleri yerlere ekonomik açıdan katkı sağlamaktadır. Böylece inanç turizmi dünya turizminin gelişmesine, evrensel barışın ve anlayışın yaygınlaşmasına, ekonomik canlanmaya, sosyalleşmeye ve inanç çekim merkezlerinin gelişmesine katkıda bulunmaktadır (Olcay ve Albuz, 2016:1). İnanç turizmi mekanları, sahip oldukları turizm potansiyeli nedeniyle özellikle tur organizasyonları içerisinde de önemli bir yer işgal etmektedir (Özgüç, 2003:84).

Günümüzde inanç turizmi dünyada önemli bir pazar büyüklüğüne ulaşmış durumdadır (Kunt ve Gülcan, 2017:185). Nitekim inanç turizm merkezleri her yıl 300 milyondan fazla ziyaretçi kabul etmektedir (Gabor, 2016). İnanç turizm endüstrisinin ekonomik büyüklüğü ise dünya genelinde 20 milyar ABD Doları kadardır (Askin, 2012). Görüldüğü üzere turizm endüstrisi içerisinde inanç turizmi oldukça önemli bir katma değere sahiptir (Huang ve Pearce, 2019:1).

İnanç mekanlarına olan ilginin günden güne artması nedeniyle dünyada birçok dini öneme sahip olan mekan, inanç turizmi adı altında ziyaret edilmektedir. Hristiyanlık, Musevilik, İslamiyet, Hinduizm, Budizm gibi dinlere ait olan kutsal mekanlar her yıl milyonlarca kişi tarafından ziyaret edilmektedir. Bu ziyaretlerin bir kısmı hac gibi bazı dini gereklilikleri yerine getirmek için yapılırken, bazıları ise manevi tatmin ve bu yerlere olan meraktan dolayı gerçekleşmektedir. 
Kuşkusuz dünyada önemli inanç merkezlerinin bulunduğu yerlerden biri de Anadolu'dur. Anadolu coğrafyası, farklı kavim, imparatorluk ve devletlere ev sahipliği yapmış ve tüm bu tarihi derinliklerin izlerini taşıyan çok sayıda kültürel mirası barındırmaktadır (Elmastaş, 2001:163). Bu mirasların başında da inançsal (dini) değerler ve zenginlikler gelmektedir. Dolaysıyla, Anadolu'nun dört bir yanında, üç semavi dinin değerlerine rastlamak mümkündür. Bu kültürel ve dini yapılar, inanç turizm potansiyeli için birer zenginliktir (Özgen, 2013:257; Benek vd., 2018; Bozkoyun ve Elmastaş, 2019).

Anadolu coğrafyası, özellikle Hristiyanlık için oldukça önemli bir yere sahiptir. Zira Hıristiyanlığın ilk zamanlarında Hz. İsa'nın havarilerine ve önemli dini şahsiyetlere ev sahipliği yapan Anadolu, Hristiyanlığın yayılmasında bir anlamda merkez olmuştur. Bu nedenle Anadolu topraklarında İstanbul, Efes, Mardin, İznik, Kapadokya Bölgesi, Antakya, Tarsus, Urfa gibi pek çok yerleşim alanı, Hristiyanlık mensupları tarafından kutsal sayılmaktadır (Başer ve Başçı, 2012:424). Bu merkezlerden biri olan Mardin, Müslüman, Hristiyan, Yezidi, Türk, Arap, Kürt gibi farklı inanç ve etnik yapıda birçok grubun bir arada yaşadığı bir saha olup, kültür ve inanç turizmi açısından büyük bir potansiyel barındırmaktadır (Günal, 2012:93). Mardin, özellikle Hristiyanlık ve onun bir kolu olan Süryanilik için son derece önemli dini yapılara ve öğelere ev sahipliği yapmaktadır. Bu yapılar içerisinde Deyrulzafaran Manastırı, Hristiyanlık ve Süryanilik için oldukça büyük bir öneme sahiptir. Mezopotamya'nın en eski topluluklarından biri olan Süryaniler, Hz. İsa'dan sonra Hristiyanlık inancını ilk kabul eden halklardan biri olmuştur. İlk kuruluş kökeni Antakya'ya uzanan Süryani Kilisesi, M. S. 4. yüzylldan itibaren Mardin ve çevresinde büyük bir kabul görmüştür. Bu durum neticesinde Mardin ve çevresinde çok önemli dini merkezler ortaya çıkmıştır. Bunların en önemlisi olan Deyrulzafaran Manastırı, M. S. 13. yüzyıldan itibaren Süryaniliğin Patrikhane Merkezi konumuna gelmiş ve bu statüsünü 7 asır boyunca sürdürmüştür. Manastır, tarih boyunca çok önemli din adamları ve yazarlar yetiştirirken, aynı zamanda değerli el yazmalarının toplandığı büyük bir kütüphaneye sahiptir (Bilge, 2008:7). Deyrulzafaran Manastırı, sahip olduğu dini, kültürel ve tarihsel önemi yanında aynı zamanda eski yapıları, muhteşem mimarisi ve insanı büyüleyen yapı harmonisiyle hem dünyanın farklı ülkelerinden hem de Türkiye' nin birçok yerinden ziyaretçi almaktadır. Özellikle Türkiye'nin birçok ilinden gelen ziyaretçiler, dini gereklilikten ziyade Deyrulzafaran Manastırı'nın manevi ortamı ve mimari yapısını merak ettiği için burayı ziyaret etmektedir. Bundan dolayı manastır Türkiye'nin en fazla ziyaretçi alan inanç çekim mekânlarından biri konumundadir.

$\mathrm{Bu}$ çalışmada Süryaniler için önemli bir dini merkez olan Deyrulzafaran Manastırı ve bu manastırı ziyaret eden ziyaretçi profili incelenmiştir. Bu amaçla, Süryaniler ve diğer meraklılarca inanç merkezi olarak ziyaret edilen Mardin kentinin $5 \mathrm{~km}$ doğusunda yer alan Deyrulzafaran Manastırı'nda bir araştırma uygulanmıştır. Araştırma sonucu elde edilen veriler, istatistiksel yöntemler kullanılarak çözümlenmiş ve yorumlanmıştır.

\section{SÜRYANILIIK VE DEYRULZAFARAN MANASTIRI}

İnsanlık tarihinin, medeniyetlerin, dinlerin ve ilk kültürlerin oluştuğu yerlerden biri olan Mezopotamya birçok millete beşiklik etmiştir. Mezopotamya'nın en eski ve en önemli halklarından biri de Süryanilerdir. Süryanilerin anavatan olarak kabul ettikleri Mezopotamya, tarih boyunca birçok kültürün bir arada yaşadığı bir kültür mozaiğiydi. Bu mozaik içerisinde Süryaniler önemli bir yere sahip olup, günümüzde bu coğrafyada varlıklarını sürdürmektedir. Bununla birlikte Süryanilerin kökeni ile ilgili bazı tartışmalar olmasına rağmen en çok kabul gören görüşe göre Süryanilerin kökeni, Mezopotamya'da M.Ö. XIV. yüzyılda ortaya çıkan Aramilere kadar dayanmaktadır (İdris, 2002:9; Günal, 2006:77, Tahincioğlu, 2019:23). Samilerin 
bir kolu olan Aramiler, M.Ö. XIV. yüzyılda Suriye'nin doğusunda ortaya çıkmışlardır. Aramiler, savaşçı bir millet olmalarına karşın, birer bağımsız prenslikler halinde bulunmaları ve bir araya gelip birleşme imkânı bulamadıkları için Asurlar, Babiller gibi büyük devlet kurma şansına sahip olamamışlardır. Kurmuş oldukları devlet M.Ö. 732'de Asurlular tarafından tarihten silinmiştir. $\mathrm{Bu}$ tarihten sonra Aramiler bir daha eski güçlerine sahip olamamış, sadece bir kısım Araminin kurduğu Abgar Krallığı (M.Ö. 132- M.S.248) gibi küçük krallıklar şeklinde devam etmiş ve kavmin bir kısmı da Hıristiyanlığın doğuşuna kadar, yabancı istilalar altında yarı göçebe bir hayat yaşamışlardır (Aydın, 1964:49, Çelik, 1996:18). Abgar Krallı̆̆ı'nın yıkılışından sonra da Aramiler bir daha devlet kuramamıştır. Hıristiyanlığın Mezopotamya'ya girmesi ile birlikte, Aramilerin bir kısmı Hristiyanlığı kabul ederek, Süryani, Keldani, Nasturi isimleri adı altında varlıklarını sürdürmeye devam etmişlerdir (Öztemir, 1988:34). Bu yaşanan süreçten sonra, Süryani sözcügü etnik yapıya göre daha baskın olmuş ve Arami sözü Süryani sözcügünün gölgesinde kalmıştır (Günal, 2006:77). Aramilerin yaşadığı bu ayrışmaya rağmen konuştukları dil olan Aramice Mezopotamya ve Ortadoğu coğrafyasında konuşulmaya devam etmiştir. Süryanilerin de doğu lehçesini konuştuğu Aramice, Hz. İsa, annesi Meryem ve havarileri tarafından da konuşulmaktaydı (Tahincioğlu, 2019:23).

Süryanilerin mensubu olduğu din olan Hristiyanlık, mensuplarının sayısı bakımından, dünyanın en büyük dinlerinden birisidir. Filistin bölgesinde ortaya çıkan ve İsa merkezli dine inananlara isim olan "Hıristiyan" kelimesi, Hz. İsa'dan sonra ortaya çıkmış ve M.S. 60 yılından itibaren yaygın olarak kullanılmaya başlanmıştır (Eroğlu, 2000:309). Hristiyanlık Hz. İsa zamanında bir din olarak ortaya çıkmamıştır. Zira Hz. İsa peygamberlik tebliğini eski Yahudi şeriatı üzerine yapmıştır. Hz. İsa'dan sonra onun cemaatini oluşturan havarileri yeni bir din tesisinde bulunmamışlardır. Ancak bir yandan ortaya çıkan hadiselerin seyri, bir yandan da Pavlos'un putperestler üzerindeki misyon faaliyetleri ve yorumları, zamanla Hristiyanlık adı altında yepyeni bir dinin ortaya çıkmasına yol açmıştır (Çelik, 1987:8). Zamanla Havariler ve arkadaşları ile Pavlos ve diğer Hristiyanlık inancını benimsemiş kişiler arasında ihtilaflar ortaya çıkmıştır. Hz. İsa'ya inananlar arasında ilk anlaşmazlık, Yahudi şeriatına uyup uymama konusunda ortaya çıkmıştır. Hristiyanlık, ilk zamanlar, yayılmaya sinagoglardan başlamıştır. Kudüs'te yaşayan Yahudilerden Hz. İsa'ya inananlar, Yahudi şeriatine uymaya devam etmiştir. Diaspora Yahudileri ise, büyük ölçüde Grek nüfuzu altında kalmalarından dolayı, Yahudi şeriatını devam ettirme konusunda pek titiz davranmamışlardır. Nitekim böyle bir çevrede yetişen Pavlos, Grek kültürünün etkisinden kurtulamamış ve diaspora Yahudileri arasında Hz. İsa'ya inananların en önemli şahsiyeti haline gelmiştir (Eroğlu, 2000:310). Havariler, Pavlos ve diğer Hristiyanlar arasında ortaya çıkan bu görüş ayrılıkları, bu din içerisinde zamanla büyük ayrışmalara ve farklı dini cemaat ve kiliselerin ortaya çıkmasına yol açmıştır.

Bu cemaatlerden biri olan Süryaniler, Hristiyanlığı ilk benimseyen halkların başında gelir. Zira Hristiyanlığın ilk kilisesi olan Antakya Kilisesi'ni Süryaniler kurmuştur. M.S.38 yılında Hıristiyan olduklarında Antakya'yı merkez edinmiş bir topluluk halinde olan Süryaniler, Hıristiyanlığı Havari Petrus (Saint Piere), arkadaşı Thomas, onun kardeşi Aday ve onların şakirtleri Agay ve Mara'dan öğrenmişlerdir. Petrus'un arkadaşı Thomas, Thomas'ın kardeşi Aday ve Mara, Süryanilerin yoğun olarak yaşadıkları Mezopotamya bölgesinin Hıristiyanlaştırılmasında büyük rol oynamışlardır (Tümer ve Küçük, 1997:303, Koluman, 2001:21). M.S. II. ve III. yüzyılda Hristiyanlık Mezopotamya, Anadolu ve dünyada hızla yayılırken, egemenliği altındaki topraklarda bu dinin yayılmasını istemeyen Roma İmparatorluğu Hristiyanlara çok büyük zulümler yapmıştır. Ancak M.S. 313 yılında Milano'da yayınlanan ferman ve İmparator Konstantin'in Hristiyanlığa girmesiyle birlikte Hristiyanlar, dinlerini diledikleri gibi yaşamaya başlamışlardır. Kısa bir süre sonra da bu din Roma İmparatorluğu'nun resmi dini haline gelmiştir. 
Hristiyan dünyasının yaşadığı bu rahatlamaya rağmen derin görüş ayrılıkları kapanmamış ve Roma, Antakya, İstanbul, İskenderiye ve Kudüs gibi merkezlerde farklı kiliseler ve görüşler ortaya çıkmıştır. Zamanla bu görüş ayrılıklara daha da derinleşerek, günümüzdeki Katolik, Ortadoks, Protestanlık gibi Hristiyan mezhepleri ve kiliseleri oluşmuştur. Hristiyan Süryani cemaati ise Antakya Kilisesine olan bağllı̆̆ından hiç ayrılmamış ve bu kilisenin en önemli mensupları olarak varlığını Mezopotamya coğrafyasında devam ettirmiştir. Katolik ve Ortodokslarca herekit (sapık) bir Hristiyan mezhebi olarak görülen Süryani cemaati, İslamiyet'in Mezopotamya'ya yayıldığı döneme kadar büyük tahribatlara uğramıştır (Çelik, 1987:1). Özellikle Bizans döneminde çok büyük zülüm ve sürgünlere maruz kalan Süryani Kilisesi, baskılara dayanamayıp patriklik makamlarını Antakya dışında Bizans'ın egemenliğinin zayıf olduğu yerlere taşıyıp durmuşlardır. Til-Hado, Halep, Malatya, Diyarbakır ve Mardin (Deyrulzafaran) bu süreçte Süryanilerin Patriklik merkezlerini taşıdıkları yerlerdir. Bizans'ın etkisinin azalmasına karşın İslamiyet'in yayılması ile birlikte Süryani Kilisesi, Mezopotamya ve Anadolu coğrafyasında iyice küçülmüş ve taraftarları oldukça azalmıştır. Küçülen Süryani cemaati, bütün bu olumsuzluklara rağmen dini ve kültürel anlamda Anadolu ve Mezopotamya bölgesinde önemli bir öğe olarak varlığını hep sürdürmüştür. Günümüzde sayıları 4 milyon civarında olduğu tahmin edilen Süryanilerin büyük çoğunluğu anavatan olarak adlandırılan Mezopotamya'nın dışında yaşamaktadır. Hindistan, Almanya, İsveç gibi ülkeler, Süryani cemaatin en fazla yaşadığı yerlerdir. Türkiye'de de yaklaşık 25000 dolayında Süryani yaşamakta olup, bunun büyük bir kısmı Mardin ve İstanbul'da yaşamaktadır (Tahincioğlu, 2019:108-109). Süryani cemaatin patriklik merkezi çok uzun bir süre Mardin'de iken, Cumhuriyetin ilk yıllarında yaşanan bir takım olumsuzluklardan dolayı patriklik merkezi Şam'a (Suriye) taşınmıştır. Bu durum günümüzde de devam etmektedir.



Şekil 1. Çalışma Sahası Lokasyon Haritası

Çalışmanın konusunu oluşturan Deyrulzafaran Manastırı, Süryaniler için hem çok önemli bir dini yapı hem de dini bir merkez konumundadır. Manastır, dini misyonu yanında tarihsel ve kültürel açıdan da Süryaniler, Mardin ve Mezopotamya halkları için büyük bir öneme sahiptir. Zira Deyrulzafaran, özellikle VI. yy.'dan sonra hem Anadolu' da hem de Anadolu dışında tanınan ve bilinen bir din ve ilim merkezi olmuştur. Ayrıca Mardin'de matbaa ilk olarak 1888 yılında Deyrulzafaran Manastırı'na getirilmiş ve uzun süre yöredeki tek matbaa olarak hizmet vermiştir. 
Erken dönem Hristiyanlığın mimari şaheserlerinden biri olan Deyrulzafaran Manastırı, Mardin kentinin $5 \mathrm{~km}$ doğusunda, Mardin Ovası'na hakim bir dağın orta yamacında kurulmuştur (Şekil 1). Manastırı oluşturan yapılar geçmiş yüzyıllardan kalmasına rağmen oldukça sağlamdırlar. Güney cephesi üç kattan oluşurken diğer cepheleri iki kattan meydana gelmektedir. Manastırın ilk yapısının büyük bir bölümü günümüze kadar olduğu gibi muhafaza edilmiştir. Aşağıdaki katta yer alan kiliselerin ve bazı odaların tavan ve duvarlarında o dönemden kalma kiremit ve büyük taşlar göze çarpmaktadır. Manastırın etrafını çevreleyen sur da manastır kadar eski olup yapı bloğunun önemli bir parçasını oluşturmaktadır (Fotoğraf 1 B, C). Deyrulzafaran'ın en önemli yapıları ise Mar Hananyo Kilisesi, Mar Petrus Kilisesi, Azizlerin Evi, Meryem Ana Kilisesi ve Firdevs Eyvanı'dır (Barsavm, 2004:3).

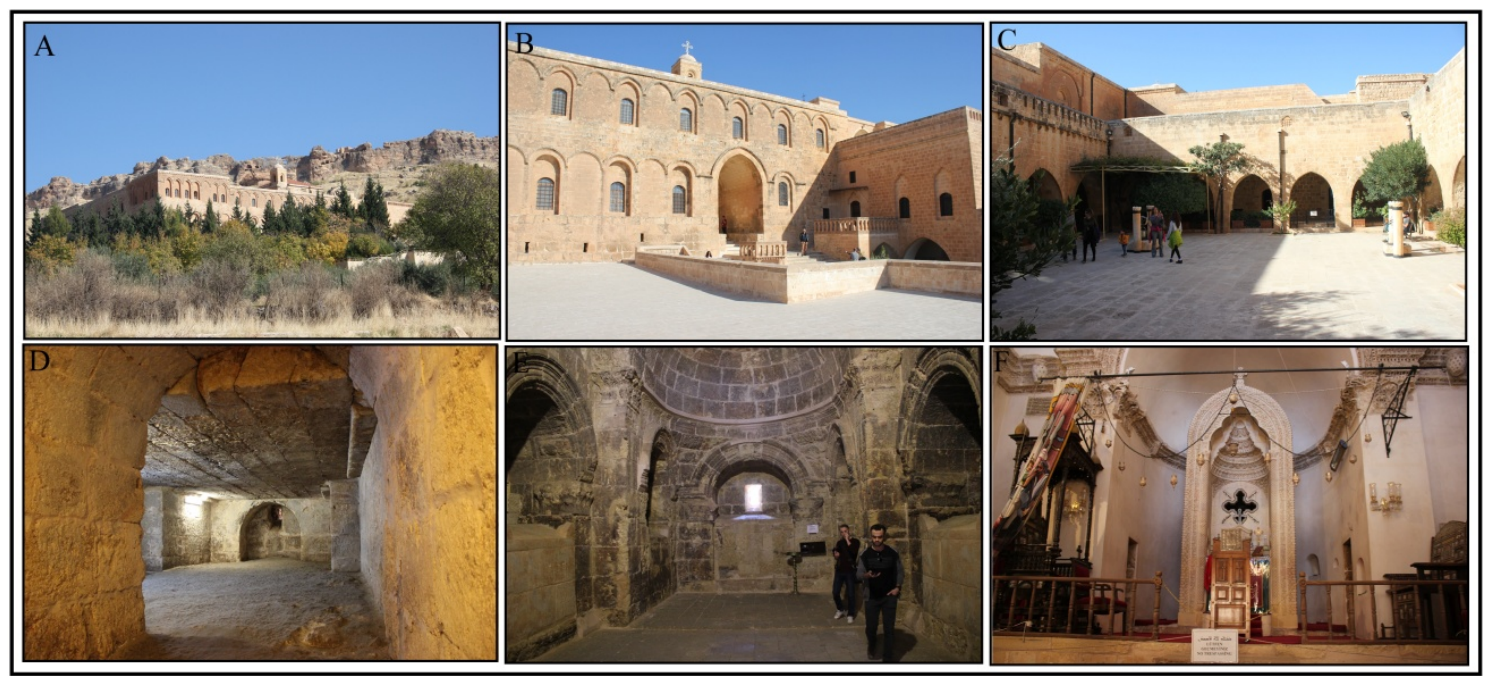

Fotoğraf 1. A: Manastırın Güneydoğu yönünden görünümü B: Dış avlu C: Eyvan D: Güneş Tapınağ 1 E: Azizler Evi F: Meryem Ana Kilisesi

Kaynak: Yazar arşivi.

Her ne kadar Deyrulzafaran Manastırı'nın mimari yapısı ve havası, manastırın tek bir dönemde inşa edildiği izlenimi veriyorsa da aslında manastır çok farklı dönemlerde yapılan eklentilerle bugünkü şeklini almıştır. Manastırın en eski mekânı, ana avlu kotunun altında kalan ve İsa'dan önceki dönemde kalan bir odadır. Bu odanın İsa'dan önceki dönemlerde bölgede bulunan ve güneşe tapan bir halk olan Şemsilere ait bir tapınak olduğu belirtilmektedir (Akyüz, 1998:15). Manastır kompleksinin en eski yapısı olarak bilinen ve manastır sakinleri arasında "Güneş Tapınağı" olarak adlandırılan bu oda, 51,5 metrekarelik bir alana sahiptir. Bu kısmın en dikkat çekici yanı odanın tavan döşemesidir. Tavan döşemesi parelelogram şeklinde kesilmiş ve düz olarak döşenen iri taş bloklardan oluşmaktadır (Fotoğraf 1 D). Taşların bu şekilde durmalarını sağlayan ise taşların üst kısımda birbirine geçip daha sonra kilit taşıyla tepede birleşmeleridir (Keser, 2002:34). Güneş Tapınağı'ndan sonra manastırın bulunduğu yer Romalılar tarafından kale olarak kullanılmıştır. M.S. 241 yılında merkezi Urfa'da olan Abgar Krallığı'na son verdikten sonra Mardin yöresini kendi topraklarına katan Romalılar, bugün manastırın bulunduğu yerde kendilerine bir kale yapmışlardır. M.S. 313 yılında Hristiyanlığın Roma İmparatorluğu'nca benimsenmesinden sonra da kale içinde bazı kiliselerin inşa edildiği tahmin edilmektedir. Ancak Romalılar M.S. 363 yılında Perslere yenilerek, bölgeden ve manastırın olduğu yerden çekilmişlerdir. Daha sonra Şleymun adında bir rahip IV. yüzyıl sonunda veya V. yüzyıl başında, Romalıların terk ettiği kaleye gelerek kendisine bir manastır kurmuştur. Illk kurucusundan dolayı ilk dönemde manastır, Mor Şleymun Manastırı olarak bilinmekteydi. M.S. 607 yılında Persler Mardin Kalesi'ni ele geçirirken bu kaleye ve manastırın bulunduğu yapılara büyük zarar vermişlerdir. Mardin ve Kefertüth Süryani Metropoliti Mar Hananyo kaleyi ve manastırı satın 
alıncaya kadar harabe şeklinde kaldı. M.S. 793 yılında dönemin yöneticileriyle anlaşan ve manastırın tamiratını yaptıran Mar Hananyo, süslemeler de ekleterek, kısa zamanda burayı meşhur bir manastır haline getirmiştir. İçinde bir kilise ve mezbaha inşa ettirmiştir. Çevresinde bağlar, zeytin ağaçları ve değişik ağaçlar dikmiştir. Birçok kitap toplatmış ve onun döneminde rahiplerin sayısı 80'e ulaşmıştır. Mar Hananyo, Rahiplere özel kanunlar tertipleyerek onlara çok ilgi göstermekteydi. Böylece Aziz Mor Hananyo, manastırın yenileyicisi olarak belirlenmiş ve manastır onun adıyla günümüze kadar ulaşmıştır. (Barsavm, 2004:7).

Günümüzde daha çok kullanılan ismi olan Deyrulzafaran adı ise manastırın etrafında yetiştirilen zafaran/safran adlı bitkiden almaktadır. Bu bitki aynı zamanda manastırın sıvasında da kullanıldığı için manastıra zafaran ve kilise isimlerinin birleşimi olan Deyrulzafaran ismi verilmiştir. Bugün daha çok kullanılan isim Deyrulzafaran'dır. Mor Hananyo'dan sonra da Deyrulzafaran Manastırı, önemini korumuş ve gelişmiştir. Özellikle M.S. IX. ve XII. Yüzyıllar arası manastır en parlak dönemini geçirmiştir (İris, 2003:116). Bu dönemde manastırın dini fonksiyonu yanında tıp, astronomi ve edebiyat gibi alanlarda eğitim veren önemli bir ilim merkezi olmuştur. Manastırın kütüphanesi tarih boyunca birbirinden değerli birçok el yazmasına sahipti. Deyrulzafaran Manastırı'nın önemi Süryani Patriklik makamının manastıra getirilmesiyle daha da artmıştır. İlk olarak 1166 yılında Patrik Mihail Rabo tarafından resmen patrik merkezi yapılan Deyrulzafaran Manastırı, böylece Süryanilerin dini merkezi konumuna gelmiştir. Ancak Patrik Rabo resmi olarak Deyrulzafaran Manastırı'nda oturmasına rağmen, önceki patrik merkezi olan Malatya'daki Mor Barsavmo Manastırı'nı da kullanmaya devam etmiştir. Bu durum sonra gelen patrikler tarafından 1293 yılına kadar sürdürülmüş, ancak bu tarihten sonra patrik İğnatius V. Yusuf Bar-Vahip tarafından sonlandırılarak, sadece Deyrulzafaran Manastırı kullanılmıştır. Böylece Deyrulzafaran Manastırı, 1293 yılından 1933 yılına kadar patriklik merkezi olmuştur (Bilge, 2008:31). Yaklaşık sekiz asır boyunca Süryanilerin patriklik merkezi olan Deyrulzafaran Manastırı, bu statüsünü 1933 yılında kaybetmiştir. Zira 1932 yılında Patrik III. İlyas Şakir, Süryani Kilisesi'ne bağlı olan cemaati ziyaret etmek için Hindistan'a gitmiş, orada hastalanarak vefat etmiştir. Bunun üzerine Süryani Ortodoks Kilisesi'nin metropolitleri Suriye'nin Humus kentinde toplanarak Afrem I. Barsavm'ı patrikliğe seçmişlerdir. O dönemde yeni patrik Türkiye'de ikamet koşullarını taşıyamadığı için patriklik makamı önce Humus'a oradan da Şam'a taşınmış olup, bu durum günümüzde de devam etmektedir.

\section{MATERYAL VE METOT}

Bu çalışmanın konusunu Mezopotamya, Anadolu ve Süryaniler için dini ve kültürel önemi oldukça yüksek olan Mardin Deyrulzafaran Manastırı oluşturmaktadır. Kültür mirası ve inanç turizm bakımından Deyrulzafaran Manastırı'nın taşıdığı önemi ve manastırı ziyaret eden ziyaretçi profilini tespit edip, yörenin kültür ve inanç turizmi potansiyelini ortaya koymak, çalışmanın temel amacını oluşturmaktadır. Çalışmada öncelikle literatür taraması ve saha çalışması yapılmıştır. Bu bağlamda Süryaniler ve Deyrulzafaran Manastırı ile ilgili daha önce yapılmış yerli ve yabancı çalışmalar incelenerek çalışma ile ilgili ön değerlendirmeler yapılmıştır. Daha sonra Deyrulzafaran Manastırı'nda ziyaretçi giriş yeri müdürü, manastır rehberi gibi bazı yetkililerle görüşülerek, manastır, gelen ziyaretçi sayıları ve profilleri ile ilgili bilgilere ulaşılmaya çalışılmıştır. Çalışma ile ilgili literatür incelemeleri ve manastırda ilgili kişilerle görüşmeler yapıldıktan sonra manastırı ziyaret eden ziyaretçi profilini tespit etmek için gelen ziyaretçilerle ziyaret sonrası gün içerisinde yüz yüze anketler yapılmıştır. Çalışmanın bu kısmı nicel araştırma tekniğine göre yapılmıştır. Anket formu hazırlanırken, literatür taraması ve uzman görüşlerinden yararlanılmıştır. Çalışmada kullanılan anket iki bölümden oluşmaktır. Birinci 
bölümde katılımclların demografik ve gelir özelliklerini belirlemeye yönelik 7 adet, ikinci bölümde ise katılımcıların genel seyahat amaçlarını ve Mardin ile Deyrulzafaran Manastırı ziyaretine ilişkin değerlendirmelerini belirlemek üzere 7 adet olmak üzere toplam 14 adet kapalı uçlu soru bulunmaktadır. Bu soruların birinde 5'li Likert Ölçeği kullanılmıştır. Anket çalışması, gelen ziyaretçi profilini en doğru şekilde saptayabilmek için 2019 yılı içerisinde Şubat, Mart, Nisan, Mayıs, Haziran, Eylül, Ekim ve Kasım ayları içerisinde ve hafta sonu ziyaretçilerle yüz yüze yapılmıştır. Bu aylar ziyaretçi yoğunluğunun en fazla olduğu aylardır. Anketin evrenini oluşturan manastır ziyaretçilerinin sayısı 2019 yılında 200.000'den fazladır. Dolayısıyla örneklem büyüklügünü hesaplamak için 200.000 sayısı baz alınarak bir hesaplama yapılmıştır. Bunun için Neuman (2010) ve Yavan'ın (2014) örneklem büyüklüğünü tespit etmek için yapmış oldukları hesaplamadan yararlanılmıştır. Buna göre evrenin büyüklügüüü temsil edebilecek örneklem sayıs1 400 olarak hesaplanmıştır (Neuman, 2010:351, Yavan, 2014:171). Anket uygulaması esnasında örneklem seçilirken, Basit Rastsal Örneklem türü tercih edilmiştir. Araştırma kapsamında derlenen veriler, belirlenen amaç doğrultusunda SPSS 22 paket programında çözümlenmiş ve yorumlanmıştır. Anketlerin değerlendirilmesinde, katılımcıların demografik özellikleri ve seyahat bilgilerine ilişkin yüzde, frekans değerleri hesaplanmıştır. Ayrıca demografik özellikler ile bazı seyahat bilgileri arasındaki ilişkinin tespitine yönelik ki-kare testinin sonuçlarına da yer verilmiştir.

\section{BULGULAR}

Deyrulzafaran Manastırı'nı ziyaret eden ziyaretçi profilini ortaya koymak üzere uygulanan anket çalışmasının ilk kısmında ziyaretçilerin demografik ve sosyo-ekonomik özelliklerini belirmeye yönelik sorular yer almıştır. Tablo 1'e göre manastırı ziyaret eden katılımcıların \%53.8'i kadın, \%46.2'si erkeklerden oluşmaktadır. Ziyaretçilerin yaş gruplarına göre dağılımına bakıldığında \%37.1'i 18-25 yaş aralığı, \%27.8'i 26-35 yaş aralığı, \%13.5'i 36-45 yaş aralığı, \%12.5'i 46-55 yaş aralığı, \%5.3'ü 18 altı yaş ve \%3.8' i ise 55 yaş üstü bireylerden oluşmaktadır. Buna göre manastırı ziyaret eden ziyaretçilerin çoğunluğu kadınlar ve 18-35 yaş aralığındaki genç nüfustan oluşmaktadır. Ankete katılan ziyaretçilerin eğitim düzeyleri incelendiğinde \%54.2'si lisans, \%16'sı lise ve dengi okul, \%13'ü yüksek lisans ve doktora, \%11.3'ü önlisans mezunu olduğu görülmektedir. Dolayısıyla manastırı ziyaret eden ziyaretçilerin büyük bir kısmı eğitim düzeyi yüksek olan bireylerden oluşmaktadır. Katılımcıların sosyo-ekonomik özelliklerini ölçmek için meslekleri ve aylık gelir durumlarına yönelik sorular sorulmuştur. Buna göre manastırı ziyaret eden ziyaretçilerin meslek gruplarına bakıldığında katılımcıların \%24.2'si öğrenci, \%23.5'i öğretmen, \%8'i serbest meslek, \%7.5'i mühendis, \%4.8'i memur, \%4'ü esnaf, \%3'ü sağlik teknikeri ve geriye kalan $\% 25$ 'i ise iş insanı, avukat, doktor gibi diğer meslek gruplarından oluşmaktadır. Katılımcıların aylık gelirlerine bakıldığında, manastırı ziyaret edenlerin \%26.8'inin aylık geliri 2501-4000 TL aralığında, \%26.2'sinin aylık geliri 0-1000 TL aralığında, \%19'unun aylık geliri 5500 TL üstü, \%16'sının aylık geliri 4001-5500 TL aralığında ve \%11.5'inin aylık geliri 1001-2500 TL aralığında gelire sahiptir. Buna göre manastırı ziyaret eden ziyaretçilerin genellikle öğretmen, mühendis, memur, esnaf, sağlık görevlisi gibi gelir düzeyi orta ve üst düzeyde yer alan toplumsal gruplardan oluştuğu anlaşılmaktadır. 
Tablo 1. Araştırmaya Katılan Ziyaretçilerin Demografik Özellikleri

\begin{tabular}{|c|c|c|}
\hline & $\mathbf{n}$ & $\%$ \\
\hline \multicolumn{3}{|l|}{ Cinsiyet } \\
\hline Erkek & 185 & 46.2 \\
\hline Kadın & 215 & 53.8 \\
\hline \multicolumn{3}{|l|}{ Yaş Aralığ } \\
\hline 18 Alt1 & 21 & 5.3 \\
\hline $18-25$ & 148 & 37.1 \\
\hline 26-35 & 111 & 27.8 \\
\hline $36-45$ & 54 & 13.5 \\
\hline $46-55$ & 50 & 12.5 \\
\hline 56 ve Üstü & 15 & 3.8 \\
\hline \multicolumn{3}{|l|}{ Eğitim Durumu } \\
\hline Yüksek Lisans ve Doktora & 52 & 13.0 \\
\hline Lisans & 216 & 54.2 \\
\hline Önlisans & 45 & 11.3 \\
\hline Lise ve Dengi Okul & 64 & 16.0 \\
\hline Illk ve Orta Okul & 18 & 4.5 \\
\hline Herhangi Bir Eğitim Kurumu Bitirilmedi & 4 & 1.0 \\
\hline \multicolumn{3}{|l|}{ Meslek } \\
\hline Öğrenci & 97 & 24.2 \\
\hline Öğretmen & 94 & 23.5 \\
\hline Serbest Meslek & 32 & 8.0 \\
\hline Mühendis & 30 & 7.5 \\
\hline Memur & 19 & 4.8 \\
\hline Esnaf & 16 & 4.0 \\
\hline Diğer & 112 & 28.0 \\
\hline \multicolumn{3}{|l|}{ Aylık Gelir Düzeyi } \\
\hline 0-1000 TL & 105 & 26.2 \\
\hline 1001-2500 TL & 46 & 11.5 \\
\hline 2501-4000 TL & 107 & 26.8 \\
\hline 4001-5500 TL & 66 & 16.5 \\
\hline 5500 Üstü TL & 76 & 19.0 \\
\hline \multicolumn{3}{|l|}{ Manastırı Ziyaret Etmek İçin Gelinen İl } \\
\hline Mardin & 67 & 17.2 \\
\hline İstanbul & 38 & 9.8 \\
\hline Gaziantep & 36 & 9.3 \\
\hline Şanlıurfa & 30 & 7.7 \\
\hline Kahramanmaraş & 26 & 6.7 \\
\hline Ankara & 21 & 5.4 \\
\hline Adana & 17 & 4.4 \\
\hline Diğer & 165 & 39.5 \\
\hline \multicolumn{3}{|l|}{ Ülke } \\
\hline Türkiye & 389 & 97.1 \\
\hline Almanya & 3 & 0.8 \\
\hline İsveç & 2 & 0.5 \\
\hline Kanada & 2 & 0.5 \\
\hline Hong Kong & 2 & 0.5 \\
\hline Diğer & 2 & 0.6 \\
\hline
\end{tabular}


Deyrulzafaran Manastırı'nı ziyaret eden ziyaretçilerin geldikleri iller ve ülkelere bakıldığında, katılımcıların Türkiye'nin birçok ilinden ve dünyanın farklı ülkelerinden geldikleri anlaşılmaktadır. Türkiye içerisinde Deyrulzafaran Manastırı'nı ziyaret eden ziyaretçilerin profilleri incelendiğinde, manastırı en fazla Mardin ili, Mardin'in çevresindeki bazı iller ile fazla nüfusa sahip olan birkaç ilden gelenler ziyaret etmektedir. Buna göre Deyrulzafaran Manastırını ziyaret eden ziyaretçilerin \%17.2'si Mardin, \%9.8'i İstanbul, \%9.3'ü Gaziantep, \%7.7'si Şanlıurfa, \%6.7'si Kahramanmaraş, \%5.4'ü Ankara, \%4.4'ü Adana ve geriye \%30'a yakın kısmı ise İzmir, Hatay gibi çok farklı illerden gelmektedir. Manastırı ziyaret eden ziyaretçilerin ülke içi ve ülke dışına göre dağılımına bakıldığında, gelen ziyaretçilerin \%97.1'i ülke içinden gelirken, \%2.9'u ülke dışından geldiği görülmektedir (Tablo 1). Ülke dışından manastırı ziyaret edenler, Almanya, İsveç, Kanada, Hong Kong, Portekiz ve Irak gibi ülkelerden gelmektedir. Ülke dışından en fazla ziyaretçi Almanya, İsveç ve Kanada gibi Süryani nüfusun yoğun olarak yaşadığı ülkelerden gelmektedir.

Tablo 2. Araştırmaya Katılan Ziyaretçilerin Dini İnançlarına Göre Dağılımı

\begin{tabular}{lcc}
\hline & $\mathbf{n}$ & $\mathbf{\%}$ \\
\hline Dini İnanç & & \\
Müslüman & 352 & 88 \\
Hristiyan (Süryani) & 13 & 3.3 \\
Hristiyan (Protestan) & 1 & 0.3 \\
Diğer & 34 & 8.5 \\
\hline
\end{tabular}

Tablo 2'de araştırmaya katılan ziyaretçilerin dini inançlarına göre dağglımı incelendiğinde, ziyaretçilerin \%88'i kendini Müslüman, \%3.3'ü Süryani Hristiyan, \%0.3'ü Protestan Hristiyan ve \%8.5'i ise deist, ateist gibi diğer inanç gruplarından birine ait görmektedir. Buna göre manastırı ziyaret edenlerin büyük çoğunluğu kendini Müslüman olarak tanımlayan bir dini gruptan oluşmaktadır. Bu da manastırın Hristiyanlık dini mensuplarından ziyade Müslümanlar tarafından ziyaret edildiğini göstermektedir.

Tablo 3'te ziyaretçilerin, seyahat biçim ve amaçları ile konaklama sürelerine ilişkin bulgular yer almaktadır. Buna göre Deyrulzafaran Manastırı'nı ziyaret eden ziyaretçilerin \%38'i arkadaş gruplarıyla birlikte Mardin'i ve Deyrulzafaran Manastırı'nı ziyaret etmiştir. Ziyaretçilerin \%25.5'i manastırı, seyahat acentesi aracılığıyla ziyaret etmiştir. Manastırı ziyaret eden ziyaretçilerin $\% 25^{\prime} \mathrm{i}$ aile fertleriyle birlikte gelirken, \%11.5'i ise bireysel olarak tek başına ziyaretini gerçekleştirmiştir. Yaş gruplarına göre ziyaretçilerin geliş şekli ele alındığında, 18-25 yaş aralığındakiler çoğunlukla bireysel ve arkadaş gruplarıyla manastırı ziyaret ederken diğer yaş grupları ise daha çok aile veya seyahat acentesi aracıllğıyla ziyaretlerini gerçekleştirmişlerdir. Ziyaretçilerin Mardin ve çevresinde kalış süreleri incelendiğinde, \%45.7'sinin Mardin'i günübirlik ziyaret ettiği görülmektedir. Manastırı ziyaret etmek amacıyla Mardin'e gelen ziyaretçilerin, \%32'si 1 ile 3 gün arasında Mardin'de konakladığı anlaşılmaktadır. Ziyaretçilerin \%6.3'ü 4-7 gün arasında yörede konaklarken, \%16'sı ise 8 gün ve üzeri sürelerde Mardin'de konaklamaktadır.

Ankete katılan ziyaretçilerin Deyrulzafaran Manastırı'nı kimden veya hangi bilgi kaynağından öğrenerek ziyaretlerini gerçekleştirdiklerine dair bulgular ele alındığında, katılımcıların \%42.4'ü eş, dost veya yakın akrabadan manastırı öğrendikleri ve bu sayede ziyaretin gerçekleştiğini belirtmişlerdir. Katılımcıların \%22.1'i manastırı seyahat acentesinin yönlendirmesiyle ziyaret ederken, \%16.3'ü bilgi kaynağı olarak interneti gösterirken, \%4'ü kilise ve İncil'den öğrenerek manastırı ziyaret ettiklerini, \%2.5'i ise bilgi kaynağı olarak televizyon ve gazeteleri belirtmiştir. 
Manastırı ziyaret eden ziyaretçilerin ziyaret nedenleri incelendiğinde, ziyaretçilerin \%78.5'i gibi büyük bir çoğunluğu manastırı merak ettiği ve ilgi duyduğu için ziyaret ettiğini belirtmiştir. Ziyaretçilerin \%11.8'i araştırma ve inceleme amacıyla, \%3'ü dini gereklilikten dolayı, \%2'si ise rekreasyon amacıyla manastırı ziyaret ettiklerini belirtmişlerdir. Ziyaretçilerin inanç gruplarına göre ziyaret etme nedenleri incelendiğinde, uygulanan Ki-Kare testi sonucuna göre Hristiyanlar ile diğer inanç gruplarına arasında anlamlı farklılıkların bulunduğu ortaya çıkmaktadır. Buna göre kendini Hristiyan olarak tanımlayanlar ziyaret nedeni olarak daha çok dini gerekliliği belirtirken, diğer inanç gruplarına mensup olanlar ise merak ve ilgiden dolayı ziyaret gerçekleştirdiklerini ifade etmiş̧ir.

Tablo 3. Araştırmaya Katılan Ziyaretçilerin Konaklama Sürelerine, Seyahat Biçim Ve Amaçlarına Göre Dağılımı

\begin{tabular}{lcc}
\hline & $\mathbf{n}$ & $\mathbf{\%}$ \\
\hline Geliş Şekli & 152 & 38.0 \\
Arkadaşlarla & 102 & 25.5 \\
Seyahat Acentesi & 100 & 25.0 \\
Aile Fertleri ile Birlikte & 46 & 11.5 \\
Bireysel & & \\
Kalıs Süresi & 183 & 45.7 \\
\hline Günübirlik & 128 & 32.0 \\
1-3 Gün & 64 & 16.0 \\
8 ve Üstü Gün & 25 & 6.3 \\
4-7 Gün & & \\
Bilgi Kaynağ1 & 169 & 42.4 \\
\hline Eş, Dost, Yakın Akraba & 88 & 22.1 \\
Seyahat Acentesi & 65 & 16.3 \\
İnternet & 16 & 4.0 \\
Kilise İncil & 10 & 2.5 \\
Televizyon, Gazete & 51 & 12.7 \\
Diğer & & \\
\hline Ziyaret Nedeni & 314 & 78.5 \\
\hline Merak ve İlgi & 47 & 11.8 \\
Araştırma ve İnceleme & 12 & 3.0 \\
Dini Gereklilik & 8 & 2.0 \\
Rekreasyon & 19 & 4.8 \\
Diğer & & \\
\hline
\end{tabular}

Anket çalışmasının son kısmında Deyrulzafaran Manastırı'nı ziyaret eden ziyaretçilerin dini mekanları ziyaret sıklığı, manastırı beğenme düzeyleri ve ziyarette en çok etkilendikleri öğeler ile ilgili ziyaretçilere sorular yöneltilmiştir (Tablo 4). Buna göre ziyaretçilerin manastır ve dini mekanları ne kadar sıklıkla ziyaret ettikleri ile ilgili bulgular incelendiğinde, \%44.8'i ara sıra ziyaret ederim şeklinde cevap verirken, $\% 26.5^{\prime} \mathrm{i}$ çok ziyaret ederim, $\% 21.5^{\prime} \mathrm{i}$ az ziyaret ederim ve \%7.2'si ise manastırı ilk defa ziyaret ediyorum şeklinde yanıtlar vermişlerdir. Bu bulgulara göre Deyrulzafaran Manastırı'nı ziyaret eden ziyaretçilerin \%70'e yakınının sıklıkla dini mekânları ziyaret ettiği görülmektedir. Dini mekânların cinsiyete göre ziyaret etme sıklığı incelendiğinde, uygulanan Ki-Kare testi sonuçlarına göre erkeklerin kadınlara göre dini mekânları daha sıklıkla ziyaret ettiği anlamlı bir şekilde ortaya çıkmıştır. Aynı şeklide Süryani Hristiyanların diğer inanç 
mensuplarına göre dini mekanları daha çok ziyaret ettikleri anlaşılmaktadır. Ziyaretçilerin Deyrulzafaran Manastırı' $n$ ı beğeni düzeylerini ölçmek için uygulanan 5'li Likert Ölçeği 'ne göre katılımcıların \%47.2'si manastırı çok beğendim, \%47'si beğendim, \%4.5'i kararsızım, \%0.8'i beğenmedim ve \%0.5'i hiç beğenmedim şeklinde yantlar vermişlerdir. Buna göre ziyaretçilerin \%95'e yakın kısmı manastırı az ya da çok beğendiklerini ifade etmişlerdir. Çalışmaya katılan ziyaretçilere son olarak manastırda sizi en çok etkileyen durum veya unsur nedir diye soru yöneltilmiştir. Bu sorudan elde edilen bulgulara göre ziyaretçilerin \%55'i mimari yapı, \%20.7'si oluşturduğu ambiyans, \%12.8'i Manevi ortamı, \%3.5'i ise din adamları şeklinde cevaplar vermişlerdir. Buna göre ziyaretçilerin büyük bir kısmı manastırın mimari yapısı ve oluşturduğu ambiyanstan etkilendiği anlaşılmaktadır.

Tablo 4. Araştırmaya Katılan Ziyaretçilerin Dini Mekânları Ziyaret Sıklığı, Deyrulzafaran Manastırı'nı Beğeni Düzeyi ve Ziyarette En Çok Etkilenen Öğelerin Dağılımı

\begin{tabular}{|c|c|c|}
\hline & $\mathbf{n}$ & $\%$ \\
\hline \multicolumn{3}{|c|}{ Manastır ve Dini Mekânları Ziyaret Sıklığ1 } \\
\hline Ara Sira Ziyaret Ederim & 179 & 44.8 \\
\hline Çok Ziyaret Ederim & 106 & 26.5 \\
\hline Az Ziyaret Ederim & 86 & 21.5 \\
\hline İlk Defa Ziyaret Ediyorum & 29 & 7.2 \\
\hline \multicolumn{3}{|c|}{ Deyrulzafaran Manastırını Beğeni Düzeyi } \\
\hline Çok Beğendim & 189 & 47.2 \\
\hline Beğendim & 188 & 47.0 \\
\hline Kararsızım & 18 & 4.5 \\
\hline Beğenmedim & 3 & 0.8 \\
\hline Hiç Beğenmedim & 2 & 0.5 \\
\hline \multicolumn{3}{|c|}{$\begin{array}{l}\text { Manastırda Ziyaretçileri En Çok Etkileyen } \\
\text { Unsur }\end{array}$} \\
\hline Mimarisi & 220 & 55.0 \\
\hline Oluşturduğu Ambiyans & 83 & 20.7 \\
\hline Manevi Ortam & 51 & 12.8 \\
\hline Din Adamları & 14 & 3.5 \\
\hline Diğer & 32 & 8.0 \\
\hline
\end{tabular}

\section{SONUÇ ve ÖNERILER}

Deyrulzafaran Manastırı inanç turizmi açısından büyük bir potansiyele sahip olmasına rağmen bu potansiyele paralel ziyaretçi kabul etmediği görülmektedir. Zira manastırı yıllık ortalama 200.000 civarında kişi ziyaret ederken, manastırın Hristiyan dünyası için taşıdığı önem ve mimari, kültürel zenginliği dikkate alındığında bu sayının çok üzerinde ziyaretçi alması gerektiği düşünülmektedir. Bunun sağlanabilmesi için ulusal ve uluslararası turizmi pazarına yönelik pazarlama ve tanıtım faaliyetlerinin hem manastır yönetimi hem de yerel ve ulusal karar vericiler tarafından yapılması gerekmektedir. Manastırı ziyaret eden ziyaretçi profili incelendiğinde, manastırın çoğunlukla yüksek eğitim düzeyine sahip, toplumsal gelir ve statü olarak orta ve üst grupta yer alan ve daha çok kadınlardan oluşan bireylerden oluştuğu görülmektedir. Bu grupların turizm endüstrisi içerisinde daha fazla harcama yapan, daha bilinçli ve kitle turizmi dışında alternatif turizme ve bilhassa kültür, inanç turizmine dahil olan bireylerden oluştuğu dikkate alındığında, tanıtım ve pazarlama faaliyetlerinin bu gruplara yönelik olarak yapılması daha fazla ziyaretçi gelmesini sağlayabilir. Aynı şekilde manastırı ziyaret eden ziyaretçi 
profillerine bakıldığında, ziyaretçilerin tamamına yakını Türkiye içerisinden olduğu ve bunların da büyük bir çoğunluğu merak ve ilgi dolayısıyla manastırı ziyaret eden Müslümanlardan oluştuğu gözlenmektedir. Halbuki Hristiyanlarca bu kadar önemli ve kutsal sayılan bir merkezin bu dinin mensupları tarafından da yoğun bir şekilde ziyaret edilmesi beklenmektedir. İnanç ve kültür turizmi kapsamında Deyrulzafaran Manastırı ve çevresi (Mardin yöresi) Almanya, İsveç, Kanada, Hindistan, Irak gibi Süryani ve Hristiyan nüfusun yoğun olarak yaşadığ tanıtım ve bilgilendirme faaliyetleri ile daha fazla Hristiyan ziyaretçinin geldiği mekana dönüşebilir.

Diğer yandan Deyrulzafaran Manastırı'nı ve Mardin yöresini ziyaret eden ziyaretçilerin geliş şekilleri incelendiğinde, çoğunlukla bireylerin ya arkadaş grupları ile ya da bireysel olarak ziyaretlerini gerçekleştirdikleri görülmektedir. Organize turlar veya diğer turizm organizasyonları ile gelen ziyaretçilerin oranı düşük bir seviyede kalmaktadır. Ancak ziyaretçi sayısında ve turizm gelirlerinde artış sağlanabilmesi için turizm endüstrisinin önemli paydaşları olan organize tur operatörleri ve diğer turizm örgütlenmelerinin daha aktif rol olması gerekmektedir. Bunun için yörede yerel mimariye uygun konaklama tesisleri ve butik otel tarzı tesislerin artması, ulaşım altyapısının çok bir iyi düzeye getirilmesi oldukça önemlidir.

Mardin ili ve içinde bulunduğu Güneydoğu Anadolu Bölgesi, ekonomik gelişmişlik düzeyi olarak Türkiye ortalamasının altında bir gelişmişliğge sahiptir. Yörede turizm faaliyetleri yerel ve bölgesel kalkınmanın önemli araçlarından biri olabilir. Bunun için yöresel ürün ve markalarının ön plana çıarılarak, bu ürünlerin gelen ziyaretçileri pazarlanması, kalkınma ve ekonomik gelişme için büyük önem arz etmektedir. Bunun yapılabilmesi için yerel ve kültürel değeri yüksek olan ürünlerinin turizm pazarına uygun olacak şekilde üretimini sağlayacak işletmelerin teşvik ve kredilerle desteklenmesi gerekmektedir. Bununla birlikte Mardin yöresindeki Süryani ve diğer Gayrı Müslim cemaatin toplumsal, kültürel ve ekonomik sıkıntılar gibi birtakım nedenlerden dolayı ülke dışına göç ettikleri görülmektedir. Bu durum hem yöredeki kültürel zenginliğin kaybolmasına hem de yörede Gayrı Müslim gruplara ait yapıların ekonomik ve sosyal nedenlerden dolayı bakımsız kalmalarına ve bu değerlerin yok olmasına yol açmaktadır. Söz konusu durum Deyrulzafaran Manastırı için de geçerli olup, kültürel ve mimari değeri çok yüksek olan bu yapının çeşitli sebeplerden dolayı zarar görmesi veya kendi kaderine terk edilmesinin önüne geçilmesi gerekmektedir. Bunun için ziyaretçi giriş ücretlerinin artırılması ve elde edilen gelirlerin manastır için kullanılmasının sağlanması ve manastırın bakım ve güzelleştirilmesi için kamu desteğinin verilmesi gerekmektedir.

Sonuç olarak dini ve kültürel olarak çok büyük bir yere sahip olan Dayrulzafaran Manastırı, tarihin her döneminde önemini ve varlığını koruyabilmiştir. Dünya kültür mirası özelliğine de sahip olan bu merkezin, korunması, dini fonksiyonun devam etmesi ve gelecek kuşaklara aktarılması son derece önemlidir. Bunun için hem manastır yönetimi ve Süryani cemaatin hem de Mardin halkı ve idarecilerinin bu büyük mirasa sahip çıkması için kolektif bir şekilde hareket ederek, bu mirası yaşatması gerekmektedir. Manastırdaki ziyaretçi sayısı günden güne artmakta ve artışla birlikte manastırdaki yapıların ve eserlerin artan bu ziyaretçi akını karşısında zarar görme ihtimali bulunmaktadır. Bunun önüne geçmek için yapıların ve eserlerin uygun şekilde muhafaza edilmesi büyük bir önem arz etmektedir.

\section{KAYNAKÇA}

Askin, D. (2012). Religious tours and spiritual travel. Retrieved The Independent Traveler, http://www.independenttraveler.com/travel-tips/none/ (Erişim Tarihi: 13.01.2020).

Akyüz, G. (1998). Deyrulzafaran Manastırı'nın Tarihi, İstanbul: Resim Matbaacilık. 
Alaeddinoğlu, F. ve Yıldız, M. Z. (2007). Türkiye' de kültür turizmi ve algılanışı. Uluslararası Asya ve Kuzey Afrika Çalışmaları Kongresi, 10-15 Eylül 2007, s.21-34, Ankara, Türkiye.

Aydın, C. (1964). Tarihte Süryaniler, İstanbul: Sıralar Matbaası.

Barsavm, A. (2004). Zihniyetlerin Bahçesinde Deyruzzafaran Manastırı'nın Tarihi ve Mardin Abraşiyesi ile Manastırlarının Özet Tarihi, Çev. Gabriel Akyüz, İstanbul: Mardin Tarihi İhtisas Kütüphanesi Yayın No: 3.

Başer, F. ve Başçı, A. (2012). İnanç Turizmi Kapsamında Aziz Pavlus Evinin Önemi ve Tanıtım Faaliyetlerine İlişkin Ziyaretçi Görüşlerinin Değerlendirilmesi, Mustafa Kemal Üniversitesi Sosyal Bilimler Enstitüsü Dergisi, 9(19), 423-443.

Benek, S. Elmastaş, N. ve Kalkan, Y. (2018). 6360 Sayılı Kanunun Van İli Kırsal Alanındaki Turizm Faaliyetlerine Etkisinin Incelenmesi, International West Asia Cogress of Tourism Research (27-30 September 2018), Congress Abstract Book, Van.

Bilge, Y. (2008). Tarih ve Yaşam Deyrulzafaran Manastırı, İstanbul: Gerçeğe Doğru Kitapevi.

Bozkoyun, M. ve Elmastaş, N. (2019). Hoşap Çayı Havzası'nın Turizm Kaynakları ve Bu Kaynakların Planlamasına Yönelik Öneriler, Turizm Araştırmaları, Çanakkale: Paradigma Akademi.

Çelik, M. (1987). Süryani Kilisesi Tarihi Cilt I, İstanbul: Yaylacık Matbaası.

Çelik, M. (1996). Süryani Tarihi (1), Ayraç Yayınları, Ankara.

Elmastaş, N. (2001). Ahlat Yöresinin Turizm Potansiyeli. Marmara Üniversitesi, Marmara Coğrafya Dergisi, 1(3), 153-182.

Eroğlu, A. H. (2000). Hıristiyanların Bölünme Sürecine Genel bir Bakış, Ankara Üniversitesi ilahiyat Fakültesi Dergisi, 41, 309-325.

Gabor, M. T. (2016). Faith-based tourism. Retrieved Business Mirror, (Erişim Tarihi: 08. 01.2020. from http://www.businessmirror.com.ph/faith-based-tourism/).

Günal, V. (2006). Mardin Il'’inde Kültürel Çekicilikler ve Turizm Amaçlı Kullanım Olanakları. Yayınlanmamış Doktora Tezi, Ankara Üniversitesi Sosyal Bilimler Enstitüsü, Ankara.

Günal, V. (2012). Mardin İ'inde Kültürel Turizm Potansiyeli, Marmara Coğrafya Dergisi, 11, 91122.

Tümer, G. ve Küçük, A. (1997). Dinler Tarihi, Ankara: Ocak Yayıncılık.

Henderson, J.C. (2002). Managing Tourism and Islam in Peninsular Malaysia. Tourism Management, 24, 447-456.

Huang K. and Pearce, P. (2019). Visitors' Perceptions of Religious Tourism Destinations, Journal of Destination Marketing \& Management, 14, 1-10.

İçöz, O. (2003). Seyahat Acenteleri ve Tur Operatörlüğü Yönetimi. (4. Baskı). Ankara: Turhan Kitapevi. İris, M. (2003). Bütün Yönleriyle Süryaniler, İstanbul: Dilek Ofset ve Matbaacılık.

Kaya. F. Cankül, D. ve Demirci, B. (2013). Türkiye'nin Önemli İnanç Turizmi Merkezlerinden Biri: Akdamar Kilisesi, KMÜ Sosyal ve Ekonomik Araştırmalar Dergisi, 15 (24): 13-24.

Keser, E. (2002). Tur Abidin Süryani Ortodoks Mimarisi, İstanbul: Tarih Vakfı.

Koluman, A. (2001). Ortadoğu'da Süryanilik, Ankara: ASAM Avrasya Stratejik Araştırmalar Merkezi Yayınları. 
Kunt. S. ve Gülcan, B. (2017). Türkiye İnanç Turizminde Zenginleşememiş Bir Ürün: Yedi Kiliseler, Journal of Recreation and Tourism Research, 4 (Special Issue 1), 184-206.

McKercher, B. and Cros, H. D. (2002). Cultural Tourism: The Partnership between Tourism and Cultural Heritage Management, Haworth Hospitality Press.

Neuman, W.L. (2010). Toplumsal Araştırma Yöntemleri: Nitel ve Nicel Yaklaşımlar (Cilt 1-2), Çev. Özge, S., İstanbul: Yayınodası Yayınları.

Okuyucu, A., ve Somuncu, M. (2013). Türkiye'de İnanç Turizmi: Bugünkü Durum, Sorunlar ve Gelecek. International Conference on Religious Tourism and Tolerance, 9-12 May1s 2013, 627-643, Konya.

Olcay, A. ve Albuz, N. (2016). İnanç Turizmi ve Türkiye'nin Tanıtımına Katkısı, Bursa: Dora Basım ve Yayın.

Özgen, N. (2013). Siirt'in İnanç Turizmi Mekânları: Ziyaret (Veysel Karani) ve Tillo (Aydınlar) Örnekleri, Doğu Coğrafya Dergisi, 27, 251-272.

Özgüç, N. (2003), Turizm Coğrafyası, İstanbul: Çantay Kitabevi.

Özgüç, N. (2007). Turizm Coğrafyası, Özellikler, Bölgeler, İstanbul: Çantay Kitapevi.

Öztemir, B.M. (1988). Yezidiler ve Süryaniler, İstanbul: Ekin Yayınları.

Reisinger, Y. (2009). International Cultural Tourism Cultures and Behaviour. USA: Elsevier.

Sargın, S. (2006). Yalvaç'ta İnanç Turizmi, Fırat Üniversitesi Sosyal Bilimler Dergisi, 16 (2), 1-18.

Sevinç, H. ve Azgün, S. (2012). Bölgesel Kalkınma ve İnanç Turizmi Bağlamında Akdamar Kilisesi Örneği, Uluslararası Sosyal ve Ekonomik Bilimler Dergisi, 2 (2): 17-21.

Tahincioğlu, Y. (2019). Tarihleri, Kültürleri ve İnançlarıyla Süryaniler, İstanbul: Butik Yayıncılık.

Union National World Tourism Organization, (2019). International Tourism Highlights 2019 Edition.

Yavan, N. (2014). Örneklem ve Örneklem Yöntemleri, Coğrafya Araştırma Yöntemleri, (Editör: Arı, Y., Kaya, İ). Balıkesir: Coğrafyacılar Derneği Yayını. 